Chapter 4

\title{
Heavy Metal Contamination in Brazilian Agricultural Soils due to Application of Fertilizers
}

\author{
Affonso Celso Gonçalves Jr., Herbert Nacke, \\ Daniel Schwantes and Gustavo Ferreira Coelho
}

Additional information is available at the end of the chapter

http://dx.doi.org/10.5772/57268

\section{Introduction}

The Brazilian grain production reaches record productivities each year and among the major crops, stand out the maize (Zea mays L.) and soybean (Glycine max L.). For these two cultures, the obtaining of the maximum yield has a fundamental importance in the current global scenario [1]. In this relentless pursuit of higher productivities, farmers use technologies related to various areas, such as new forms of fertilizer and pesticide application, different fertilizers, crop breeding, equipment and techniques of planting and harvesting. In order to increase the efficiency in this activity, due to the increased requirement for competitiveness of economic globalization, one of the tools found by farmers is the use of fertilizers containing micronutrients in their crops [2]. Among the various factors of production, the need of balanced and sustainable fertilizers occupies a prominent place, which should include not only the primary and secondary macronutrients, but also micronutrients, which are not considered in routine fertilization by most farmers. Currently, with the advancement of the industries of fertilizers, micronutrients are added directly in the formulation of basic fertilizers $\left(\mathrm{N}_{2}: \mathrm{P}_{2} \mathrm{O}_{5}: \mathrm{K}_{2} \mathrm{O}\right)$, which can be found in the market of domestic and imported agricultural inputs [3]. Among the several micronutrients used in Brazilian and Global agriculture, zinc ( $\mathrm{Zn})$ is a major one, having its need scientifically established over 70 years being its main functions related to photosynthesis, respiration, protein synthesis and plant membrane permeability [2].

Nutrient uptake by crops is influenced by various factors, including climatic conditions such as rain and temperature, genetic differences between varieties, type of soil, nutrient content of soil and various cultural practices. 
In the strategy of reducing costs, both in manufacture of fertilizers, as well in croplands, the use of industrial waste for the obtaining of micronutrients has been widely used. These wastes, when used appropriately and rationally present themselves as a good solution for agriculture, but their improper use can cause serious damage to soil, plants and human beings. Several researches are touting in scientific works, facts that generate severe criticism to the fertilizer industry, mainly because the involvement of these industries in operations that endanger the environment, where the main factor is the use of raw materials containing toxic metals such as cadmium $(\mathrm{Cd})$, lead $(\mathrm{Pb})$ and chromium $(\mathrm{Cr})$ in the manufacture of fertilizers [4]. In that way, the fertilizers used to supply micronutrients have often, in their composition, in addition to the desirable elements, toxic metals such as $\mathrm{Cd}, \mathrm{Pb}$ and $\mathrm{Cr}[5,6]$.

The purpose of this chapter is to assist in developing a more adequate environmental legislation, that ensures a sustainable environment and a production of quality food. In that way, this chapter highlight the lack of criteria, in the current Brazilian environmental legislation, regarding the allowed limits of toxic heavy metals in agricultural soils and in the use of fertilizers contaminated with heavy metals in agriculture, as well, demonstrate that the use of these contaminated inputs can cause degradation of agricultural soils, making food production unviable at these locations. Furthermore, it was made the study of three cases about the existence of fertilizers contaminated with toxic metals in Brazilian agriculture and the impact caused by its use. The chapter also presents some strategies for recuperation and remediation of soils contaminated with toxic heavy metals.

The presence of heavy metals in fertilizers is a extremely important subject, since investigations in Brazil, coordinated by prosecutors in São Paulo, show evidence of entry loads containing toxic waste through irregular importation and smuggling, several times in Brazilian ports. These investigations shown that companies and manufacturers of agricultural inputs, are importing these toxic chemicals from United States, Canada, Mexico, Spain, Holland and England to be used as raw material in the manufacture of fertilizers to supply micronutrients.

Brazil presents itself as one of most promising nations of contemporary and future world, however, for the effective consolidation of its presence among the great powers is extremely necessary maintain the sustainability of its agroecosystem. Therefore, the Brazilian agricultural activity should be developed without damaging the environment and thus continue to grow in a rational and appropriate way, avoiding harm to future generations. In the world of agribusiness, which needs to be highly competitive, concepts such as traceability, environment and risk assessment are fundamental starting points for those who want to establish and grow.

\section{Potential contamination of soil by agricultural activities}

Due to its continental dimensions, Brazil has a great diversity of soil types in different regions of the country. Most of these soils have limitations for agriculture, characteristic of tropical regions such as acid, deep and highly weathered soils, with low nutrient availability and high exchangeable acidity $\left(\mathrm{Al}^{3+}\right)$, resulting in a low cation exchange capacity and low availability of $\mathrm{P}$ [7]. 
These factors highlight the need for adopting management strategies that aim to increase the chances of good crop of the culture when grown in soils of low fertility, giving them the ability to meet the nutritional requirements of these plants. The practices of fertilization and soil amendment aim to make soil suitable for the development of major crops, providing the necessary nutrients for the plants and decreasing the acidity of the soil. These practices are adopted throughout the world, and are based on the prerogative of the need to produce food to sustain the world population that grows rapidly each year.

According to the Food and Agriculture Organization of the United Nations (FAO) [8], in 1980 there were 4.4 billion people on the planet, 5.7 billion in 1995 and 6.9 billion in 2010. Studies estimate that by 2050 there will be 9.4 billion people and in 2200 about 11 billion [9]. Based on this scenario, agricultural activities have expanded greatly since 1945, currently holding approximately 38\% of the land surface. Between 1985 and 2005, the acreage increased about $7 \%$, generating large increases in food production [10].

This pressure on agricultural activities promotes an increasing fertilizer consumption per each year that goes around the globe (Figure 1). Studies show that in the early 60's used to be about 146 million tons of fertilizer, increasing in 2010 to 176 million of tons, demonstrating a significant increase in the consumption of these inputs [11]. Also according to the International Fertilizer Association (IFA) [11], Brazil is the fourth largest consumer of mineral fertilizers $\left(\mathrm{N}: \mathrm{P}_{2} \mathrm{O}_{5}: \mathrm{K}_{2} \mathrm{O}\right)$ in the world, only behind China, India and the United States. In recent years the consumption of nutrients by Brazilian agriculture has increased considerably being that in 1961 Brazil was only the 25th world consumer, however in the 1990, the country was already appearing as the seventh in the rankings. Regarding to micronutrients, there is an increase in consumption of 13.3 times in the period 1990-2003 [12].

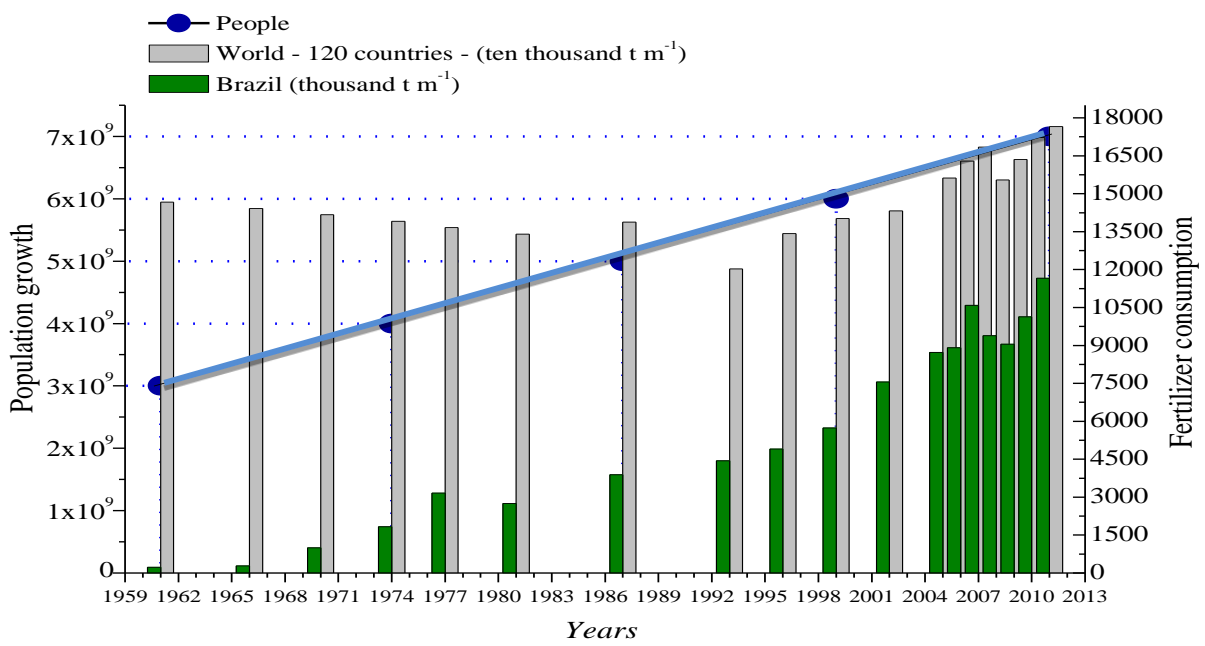

Figure 1. Population growth and consumption of fertilizers in Brazil and in the world [11] 
However the use of these products is often not done correctly. The plan for fertilizer recommendation involves planning for the collection of soil samples, soil chemical analysis and recommendation by an appropriate professional, something that many producers do not perform, often using pre-determined recommendations without professional assistance. Another problem is the lack of crop rotation and the use of highly productive cultivar which, according to reference [13], require intense macronutrient application, resulting in micronutrient deficiencies in the soil.

Overuse of fertilizers can also provide soil contamination, it increases the concentration of a particular element or substance of environmental interest above its naturally occurring in the soil [7]. This contamination is related to eutrophication (excess nutrients), in this case the major nutrients to be considered are nitrogen $(\mathrm{N})$ and phosphorus $(\mathrm{P})$. Another concern is the availability of harmful elements such as toxic metals. These elements can express their pollutant potential directly on soil organisms, due to the availability to plants in phytotoxic levels, plus the ability to transfer to the food chain through the own plants, or by contamination of soil and water resources [14].

The presence of harmful elements in fertilizers is worrying because until the 70's, most fertilizers were obtained directly from ores found in nature, and although they also contained toxic metals, the beneficiation process of this material was less offensive from the environmental standpoint, because the contaminant levels were very low [6]. Recently, the shortage of mineral resources and modern extraction methods required large investments in equipment and technology, creating a technical difficulty and the pursuit of lower costs of production, which eventually encouraged companies to seek a cheaper solution such as using industrial waste, that may be feasible since it does not contaminate the environment. However, according to the Environmental Sanitation Technology Company of São Paulo State (CETESB) [15], in São Paulo, until the end of 2012, 4572 contaminated areas were found, and approximately $4 \%$ of these areas were contaminated with industrial waste, and among the contaminants, toxic metals are in 4th place, behind Polycyclic aromatic hydro carbons contaminants (PAHs), aromatic solvents and liquid fuels.

Between the sources of soil contamination from waste, there is the contamination of sewage sludge, that even though has a variable composition, with macro, micro nutrients and organic matter, their use may be limited by the presence of pathogens and toxic metals $[16,17]$. Studies evaluating the use of sewage sludge in sugarcane found that the doses used increased levels of chromium, nickel ( $\mathrm{Ni}), \mathrm{Pb}$ and zinc $(\mathrm{Zn})$ in the soil [18].

Reference [19] studying the availability of Cd in dystrophic soil submitted to the application of sewage sludge, observed that at the first hour of contact between the sewage sludge and soil occurred transference of $\mathrm{Cd}$ to the solution. After this interval, the $\mathrm{Cd}$ concentration in the solution decreases, occurring stabilization in the following hours, due to adsorption and ion exchange which act providing less metal. According to the authors, in all observed time intervals, the levels of Cd were higher than reference values for CETESB $\left(<0.5 \mathrm{mg} \mathrm{kg}^{-1}\right)$ [20], which characterize the contamination of the soil by sewage sludge. 
The use of pig manure as fertilizer is also a practical often carried out mainly in south of Brazil, however, some studies have shown risks as to its overuse. Reference [21] evaluated the accumulation of metals in the soil under the systematic application of swine manure, and found an increase in the availability of copper $(\mathrm{Cu})$, zinc and manganese (Mn). The authors also claim that in these cases there is a need to monitor these elements over time, so that the total contents do not exceed the critical values. In study conducted in China [22], the application of manure in soil for 16 years resulted in higher accumulation of $\mathrm{Cd}$. One of the major sources of metals such as $\mathrm{Pb}, \mathrm{Ni}, \mathrm{Cr}$ and $\mathrm{Cd}$ in pig manure is mineral supplied by commercial feed [21].

The metals are also components of many pesticides, mainly $\mathrm{Cu}, \mathrm{Zn}$ and $\mathrm{Pb}$, which cause high soil contamination by these elements [23], another case is the use of $\mathrm{Cu}$, that has been used since 1917 for the Bordeaux mixture [24]. In a study conducted in Caetés watershed in the county of Paty's Ensign, Rio de Janeiro, Brazil, it was aimed to evaluate the soil contamination by toxic metals, from the intensive use of agrochemicals, in which the authors found an increase in the total levels of metals in soil, stream water and dams. The soil metal concentration not reached critical established levels, however the result was worrying about the water stream and dam, which showed total contents of $\mathrm{Cd}, \mathrm{Mn}$ and $\mathrm{Pb}$ above maximum standards established by the Brazilian legislation [23].

In England and Wales, reference [25] developed an inventory on the input of metals in agricultural soils. Forms of contamination are the most diverse, the main sources are generated by atmospheric deposition, sewage sludge, manure, inorganic fertilizers, lime, agrochemicals, irrigation water and industrial waste.

All these reports point to industrialization as the main cause for the large amount of metal dispersed in the environment, and human as the protagonist of all this pollution, because usually mankind seeks the easiest way supply their needs while generating countless volumes of waste. These actions put us in the position of predator. And thus there is a need of legislations that seek to limit the presence of these contaminants in the soil. In Table 1, the international maximum levels of metals allowed in soils of various places show what would be, in theory at least, a concern of many countries in the world about metal contamination.

\begin{tabular}{|c|c|c|c|c|c|}
\hline \multirow{2}{*}{ Countries } & \multicolumn{5}{|c|}{ Toxic Metals (mg kg $\left.{ }^{-1}\right)$} \\
\hline & As & $\mathrm{Cd}$ & $\mathrm{Pb}$ & $\mathrm{Cr}$ & $\mathrm{Hg}$ \\
\hline (*) European Comunities & - & $1-3$ & $50-300$ & - & $1-1,5$ \\
\hline${ }^{(* *)}$ United States & 14 & 1.6 & $50-300$ & 1500 & 0.5 \\
\hline$\left.{ }^{(\star \star}\right)$ Poland $(1977-1993)$ & 30 & $1-3$ & $70-150$ & $50-80$ & 5 \\
\hline$\left.{ }^{(\star \star}\right)$ Germany $(1984-1992)$ & 20 & $3-1.5$ & 100 & 100 & 2 \\
\hline${ }^{(* *)}$ United Kingdon & 10 & $3-15$ & $500-2000$ & - & - \\
\hline${ }^{\left({ }^{*}\right)}$ Austria & 50 & 5 & 100 & 100 & 5 \\
\hline
\end{tabular}

Source: * $\left.{ }^{*} 26\right], * *[27]$

Table 1. Maximum permitted levels of toxic metals in the soil in some countries 
Currently in Brazil, the legislation that deals about soil contamination is Resolution $n^{\circ} .420$ of 2009 of the National Council of Environment (CONAMA) [28], which aims to establish the criteria and values that guide of soil quality as the presence of chemical substances, among them the toxic metals. The resolution establishes three categories of guiding values which are: The Reference Value Quality (RVQ) which is the concentration of a substance that will define the natural quality of the soil, based on previous studies for each Brazilian state, the Prevention Value (PV), which refers to the concentration limit of a substance in the soil, and the Investigation Value (IV) which is the concentration of a substance in the soil of which there are potential risks, direct or indirect, to human health. Table 2 shows the values set for preventing and detecting toxic metals in soil.

However, the Resolution $n^{\circ} .420$ is being severely questioned by authorities and researchers, since it present several misconceptions that violate the Federal Constitution regarding the "preservation, enhancement and restoration of environmental quality propitious to life" (this issue will be addressed with greater emphasis on section 5 of this chapter).

\begin{tabular}{ccccc}
\hline \multirow{2}{*}{ Metal } & PV & \multicolumn{3}{c}{ IV } \\
\cline { 3 - 5 } & & Agricultural Area & Residential & Industrial \\
\hline $\mathrm{As}\left(\mathrm{mg} \mathrm{kg}^{-1}\right)$ & 15.0 & 35.0 & 55.0 & 150.0 \\
\hline $\mathrm{Cd}\left(\mathrm{mg} \mathrm{kg}^{-1}\right)$ & 1.3 & 3.0 & 8.0 & 20.0 \\
\hline $\mathrm{Pb}\left(\mathrm{mg} \mathrm{kg}^{-1}\right)$ & 72.0 & 180.0 & 300.0 & 900.0 \\
\hline $\mathrm{Cr}\left(\mathrm{mg} \mathrm{kg}^{-1}\right)$ & 75.0 & 150.0 & 300.0 & 400.0 \\
\hline $\mathrm{Hg}\left(\mathrm{mg} \mathrm{kg}^{-1}\right)$ & 0.5 & 12.0 & 36.0 & 70.0 \\
\hline
\end{tabular}

PV: Prevention Value; IV: Investigation value

Table 2. Values guiding to the presence of toxic metals in Brazilian soils in accordance with Resolution $n^{\circ} 420$ of 2009 of CONAMA [28]

\section{Fertilizers versus contaminants}

There are three different categories of agricultural fertilizer: macronutrient fertilizer to supply major nutrients (N, P and K); macronutrient fertilizer to supply secondary nutrients [calcium (Ca), magnesium (Mg) and sulfur (S)] and micronutrients [Cu, Zn, Ni, Mn, iron (Fe), molybdenum $(\mathrm{Mo})$, boron $(\mathrm{B})$, chlorine $(\mathrm{Cl})$, sodium $(\mathrm{Na})$, cobalt $(\mathrm{Co})$ and silicon $(\mathrm{Si})]$. All of these nutrients can be applied through simple fertilizer (only one nutrient) or compound form (formulations with more than one nutrient).There is a further classification based on the essentiality of nutrients, where metals may be classified as essentials, such as $\mathrm{B}, \mathrm{Cu}, \mathrm{Fe}, \mathrm{Mn}$, Mo and Zn; beneficial, such as $\mathrm{Co}, \mathrm{Ni}$ and $\mathrm{V}$; and toxic, such as $\mathrm{Cd}, \mathrm{Cr}, \mathrm{Hg}$ and $\mathrm{Pb}$. Thus, it should be noted that the essential and beneficial elements can become toxic at high concentrations [30]. 
According to reports developed by the United States Environmental Protection Agency (USEPA) [31] and The Weinberg Group (requested by The Fertilizer Institute) [32], the main metal contaminants that are found in agricultural fertilizers are $\mathrm{Cd}, \mathrm{Cr}, \mathrm{Co}, \mathrm{Cu}, \mathrm{Pb}, \mathrm{Mo}, \mathrm{Ni}$, $\mathrm{Zn}$, arsenic (As), mercury (Hg) selenium (Se), vanadium (V) and radio $266(\mathrm{Ra})$. It can be observed in this list, that among the metals commonly found as contaminants in fertilizers, occur the presence of micronutrients, required for plant development.

According to USEPA [31], among the fertilizers used to supply macronutrients, the phosphate shown the highest levels of toxic metals (especially $\mathrm{Cd}$ ), followed by nitrogen and potassium fertilizers. With respect to micronutrients, the sources used to obtain it are varied, resulting in the occurrence of fertilizers from low to high levels of metals. In general, micronutrient sources have higher level of contaminant in comparison to sources of macronutrients, on the other hand, are applied larger amounts of fertilizer to supply the macronutrients, therefore, the possibility of soil and environment pollution with the use of any type of contaminated fertilizer is real and should be seriously studied.

The presence of contaminants in fertilizers occurs most of the time with the use of industrial waste or low cost sources for raw materials. These sources, when treated and used properly and rationally, present themselves as a good alternative to agriculture, however its improper use can cause serious damage to the soil, plants and the human beings.

This fact becomes even more important in the case of fertilizers to supply micronutrients, which often are obtained from raw materials originated from industrial wastes, which may show, in addition of the desirable elements, toxic metals. In this situation, the benefits are highly attractive for the fertilizer industries, once these companies acquire low quality raw material at low costs, without generating any type of waste, incorporating everything in their products.

One of the main cases regarding the presence of contaminants in fertilizers happened in the 90 s in the United States, where many farmers and social actors reported the possibility of the presence of toxic metals in these inputs. The impact generated and population pressure led to the development of several research regarding the contamination of fertilizers and soil pollution, culminating with the publication by the U.S. government, of the first law regulating the content of toxic elements in the United States in 1998. From these studies and based on Canadian law, in 2002, the USEPA published the federal law that regulates the production of fertilizers to supply Zn from industrial waste [33].

Another case reported in the literature is the presence of contaminants in raw materials from China. In a publication from the Washington Department of Ecology (WDE) [34] it was reported the presence of $\mathrm{Cd}$ in raw materials for the manufacture of fertilizers, with samples showing more than $20 \%$ of Cd, i.e., more than 200,000 ppm. It is also reported that the final products produced with the use of these contaminated sources presented 10,600 ppm of Cd. The report also warns that $\mathrm{Cd}$ present in the analyzed material does not naturally occur in natural mineral sources, leading to the conclusion that the incorporation of $\mathrm{Cd}$ or the use of wastes contaminated with this metal was occurred. 
In Brazil, there are frequent reports of companies selling fertilizer, mineral and organic, outside the standard quality. The most common cases are related to the presence of nutrients amounts below the specified labels, since this factor is more investigated. However, there are few studies evaluating the presence of toxic metals in these inputs, although the few that were conducted demonstrated the presence of these contaminants in fertilizers $[6,35,36]$.

Currently, most grain-producing countries and other plant materials have laws regarding the limits of metals in fertilizer, which are presented in Table 3, where it can be observed a large variation between the allowed values. In general, the stipulated limits are for metals in phosphate fertilizer and micronutrient fertilizers, but there are some normatives that consider fertilizers in general, regardless of its composition or purpose. The limits of toxic metals can also be determined based on the amounts of nutrients or total amount in fertilizers.

\begin{tabular}{|c|c|c|c|c|c|}
\hline \multirow{2}{*}{ Country } & \multirow{2}{*}{ Fertilizer type } & As & $\mathrm{Cd}$ & $\mathrm{Pb}$ & $\mathrm{Cr}$ \\
\hline & & \multicolumn{4}{|c|}{ - } \\
\hline Switzerland ${ }^{1}$ & Phosphate & NA & 50.0 & NA & NA \\
\hline Finland $^{1}$ & Phosphate & NA & 50.0 & NA & NA \\
\hline Sweden ${ }^{1}$ & Phosphate & NA & 100.0 & NA & NA \\
\hline Norway $^{1}$ & Phosphate & NA & 100.0 & NA & NA \\
\hline Denmark ${ }^{1}$ & Phosphate & NA & 110.0 & NA & NA \\
\hline Belgium ${ }^{1}$ & Phosphate & NA & 210.0 & NA & NA \\
\hline Germany ${ }^{1}$ & Phosphate & NA & 210.0 & NA & NA \\
\hline Austria ${ }^{1}$ & Phosphate & NA & 275.0 & NA & NA \\
\hline U.S. (California) $)^{2}$ & Phosphate & $2.0^{*}$ & $4.0^{*}$ & $20.0^{*}$ & NA \\
\hline U.S. (Washington) ${ }^{3}$ & Phosphate & 13.0 & 165.0 & 61.0 & 1.0 \\
\hline Australia ${ }^{1}$ & Phosphate & NA & 300.0 & NA & NA \\
\hline$J_{a p a n}{ }^{1}$ & Phosphate & 50.0 & 343.0 & 100.0 & 5.0 \\
\hline New Zealand ${ }^{1}$ & Phosphate & NA & 280.0 & NA & NA \\
\hline U.S. $(\text { Texas) })^{4}$ & Anyone & 41.0 & 39.0 & 300.0 & 17.0 \\
\hline Canada $^{1}$ & Anyone & 75.0 & 20.0 & 500.0 & NA \\
\hline China $^{4}$ & Anyone & 50.0 & 8.0 & 100.0 & NA \\
\hline U.S. (California) & Micronutrient & $13.0^{* *}$ & $12.0^{\star *}$ & $140.0^{* *}$ & NA \\
\hline U.S. (Washington) & Micronutrient & $112.0^{\star *}$ & $83.0^{\star *}$ & $463.0^{\star *}$ & $6.0^{* *}$ \\
\hline Australia & Micronutrient & NA & 50.0 & 2000.0 & 5.0 \\
\hline
\end{tabular}

1 [38], 2 [39], 3 [40], 4 [41]; * - Maximum allowed value per percentage point of $\mathrm{P}_{2} \mathrm{O}_{5}$ in the fertilizer; ** - Maximum allowed value per percentage point of the micronutrients sum in the fertilizer; NA - not available

Table 3. International maximum limits of contaminants allowable in fertilizers 
The Brazilian fertilizers law is based on the Normative Instruction (NI) 27/06 [37], which states like contaminating toxic metals, the elements $\mathrm{As}, \mathrm{Cd}, \mathrm{Pb}, \mathrm{Cr}$ and $\mathrm{Hg}$, determining the maximum allowable limits of these metals in four different categories of fertilizers (Table 4).

\begin{tabular}{|c|c|c|c|c|c|}
\hline \multirow{2}{*}{ Fertilizer type } & \multicolumn{5}{|c|}{ Maximum permitted quantity of the metal contaminant ( $\mathrm{mg} \mathrm{kg}^{-1}$ ) } \\
\hline & As & $\mathrm{Cd}$ & $\mathrm{Pb}$ & $\mathrm{Cr}$ & $\mathrm{Hg}$ \\
\hline $\begin{array}{l}\text { Simple mineral fertilizer to } \\
\text { suply } \mathrm{P}_{2} \mathrm{O}_{5}\end{array}$ & $2.0^{\star}$ & $4.0^{*}$ & $20.0^{\star}$ & $40.0^{*}$ & $0.05^{*}$ \\
\hline $\begin{array}{l}\text { Compound mineral } \\
\text { fertilizer with } \\
\text { micronutrient }\end{array}$ & $500.0^{* *}$ & $15.0^{\star * *}$ & $750.0^{* *}$ & $500.0^{* *}$ & $10.0^{* *}$ \\
\hline $\begin{array}{l}\text { Compound mineral } \\
\text { fertilizer with } \\
\text { macronutrient and } \\
\text { micronutrient }\end{array}$ & 250.0 & 57.0 & 1000.0 & NA & NA \\
\hline $\begin{array}{l}\text { Mineral fertilizer to suply } \\
\text { micronutrient }\end{array}$ & 4000.0 & 450.0 & 10000.0 & NA & NA \\
\hline
\end{tabular}

Table 4. Maximum allowable limits for metal contaminants in Brazilian fertilizers [37]

There are some doubts in relation to NI 27/06, which consider the legislation incipient, since that it does not determines which raw materials can be used as sources of nutrients in the fertilizers. Nutrient sources for macronutrients generally present good quality, however, for micronutrients, the use of low quality materials is frequently observed in Brazil, as mentioned previously, resulting in a possible contamination of the environment.

The legislation also does not tell how it will be the inspection of fertilizers industries, moreover tolerating the presence of contaminants in amounts up to $30 \%$ higher than the accepted values (Table 4). Another worth mentioning fact, is that the limits should be revised, since Article 5 affirms the need of a revision of the values predicted by NI 27/06 four years after its publication.

Nowadays, still does not exist an adequate legislation in Brazil regarding the use of toxic waste in the production of micronutrients. However, there are technical studies which classify these elements as hazardous materials, an example is the NBR 10004 of the Brazilian Association of Technical Standards (ABNT) [42], which stablish that the use of this wastes may present a risk to public health, causing or contributing to an higher incidence of diseases and mortality, also presenting adverse effects on the environment when handled or disposed inappropriately.

Another issue that is being discussed by the scientific community is that the determination of contaminants limits in fertilizers provides for the industries the possibility to include, as a source of nutrients, contaminated materials or with low quality, i.e., by the laws, the govern- 
ment provided the industries, exactly what they wanted, the possibility to incorporate lowquality raw materials and contaminated to supply nutrients [43]. It is observed so that there is a strong influence of the fertilizer industry in the studies and laws that limit the contaminants in these materials, showing that this problem is not only related to the environmental field, but also with the political and economic sector.

\section{Metals: Toxicity in the foodchain}

Due to its mobility in aquatic systems and to its toxicity to life forms, the toxic metals or heavy metals, once in surface or in groundwater, are mentioned as one of the most problematic inorganic contaminants in the environment.

The toxic meals are strongly pollutants elements and present many harmful effects to ecosystems, causing physical-chemical alterations to water, what promote the decrease of water quality and mortality of the fauna and flora, prejudicing consequently, the human health [44].

The term heavy metal, is many times used with connotations of pollution and toxicity. However, "heavy" is conventionally used to imply the high density of the metal, referring to the pure element or to an alloy of metallic elements. The expression heavy metal apply to elements which have specific mass higher than $5 \mathrm{~g} \mathrm{~cm}^{-3}$ or which have atomic number higher than 20 [6].

Some metals, as the case of $\mathrm{Cd}, \mathrm{Pb}, \mathrm{Ni}$ and others, even when its presence is diluted in waters, many times in undetectable quantities, have recalcitrant effect, i.e., its persistence in the environment imply in process as biomagnification, which regards to the accumulation of these harmful substances in the many trophic levels of the ecological chains of ecosystems.

The contamination by toxic metals in animals can occur due to inhalation, skin penetration or ingestion of contaminated waters and foods, this last caused mainly by the capacity of plants in bioccumulate these elements in high proportions and later offer them to animals and human beings [45].

In animals, the toxic metals act in highly specific reactions, enzymatic in the most part and in alterations in systems that evolves these reactions, resulting in negative effects. One classic example is the metalloenzymes, in which dimensional structure is changed if one "intruder metal" binds to its active site, what prevents the enzymatic action [46].

Metal contaminations in the environment results from a sum of natural processes, between which also make part the natural sources of contamination, however, it is a common sense that the sources so called anthropogenic are more frequent when compared to the natural sources of contamination [47].

Significant increases of the metals concentrations are found in areas of intense industrial activity, where the accumulation can be many times higher than the average levels from non-contaminated areas. However, areas distant from the industrial centers in many cases also show metals contamination, due to the atmospheric transportation of these com- 
pounds [48] and in the case of agricultural soils, due to the use of fertilizes contaminated with these metals [6].

The contamination by metals is arising from the continuous disposal of industrial, domestic or livestock wastes in soils, rivers, lakes and seas. These pollutants include the toxic metals, which cause great concern to public health, because they are incorporated very easily in the tropic chain. These harmful elements cannot be destroyed by biological degradation, as in the case of the most part of organic pollutants. Incidences of the accumulation of metals in fish, oysters, mussels, sediment and other components from the aquatic systems have been reported in many countries around the world $[49,50]$.

Once the metals are present in cultivated soils, they are likely of radicular absorption by plants. It is important to point out that some of these elements present biological function whereas others are much known as toxic even in low concentrations. This way, the plants can be considered as constituents of the foundation of the trophic chain, causing great concern due to the possibility of the occurrence of toxic concentrations of certain metals which are transported from plants to higher levels of the food chain [51].

The toxic metals are not only subjected to radicular absorption by plants when presents in the soil solution, because may also occur the fixation of the metals in the soil particles, seepage/ leaching to lower levels of soil or even the surface runoff, reaching the groundwater, rivers, lakes and seas. In general, there are two types of soils in Brazil, sandy and clayey, so that in sandy soils, due to the low ion exchange capacity, the metals are easily moved in the environment by leaching or surface runoff, reaching easily the hydric resources. In the other hand, in clayey soils, due to the higher ion exchange capacity, the metals tend to stand immobilized in the soil particle, becoming available for the plants in more than one cultivation season.

The toxic metals resulting from the anthropogenic activities, when disposed incorrectly in the environment, directly or indirectly reaches the top of the chain, i.e., humans will have contact with these elements by the consumption of food from vegetal or animal origin, contaminated by water, soil or air. Once in the human organism, these metals present cumulative character, i.e., are accumulated in the live tissues, i.e., hardly are eliminated by the organism. Down below are related some of the characteristics of some toxic metals and its respective collateral effects caused to human organisms.

\subsection{Arsenic (As) - CAS ID 7440-38-2}

In humans, the ingestion of high levels of arsenic can result in death. Exposure to lower levels can cause nausea and vomiting, decreased production of red and white blood cells, abnormal heart rhythm, damage to blood vessels, and a sensation of "pins and needles" in hands and feet. The ingestion of inorganic arsenic can increase the risk of skin cancer and cancer in the liver, bladder, and lungs. Inhalation of inorganic arsenic can cause increased risk of lung cancer. Exposure to higher than average levels of arsenic occur mostly in the workplace, near hazardous waste sites, or in areas with high natural levels. At high levels, inorganic arsenic can cause death [52]. 
Aquatic organisms accumulate arsenic mainly as inorganic forms, and some of the organisms such as phytoplankton, bacteria, etc. transform them into methylated and organic forms [53].

As is associated with ores containing metals, such as copper and lead. Arsenic may enter the environment during the mining and smelting of these ores. Small amounts of arsenic also may be released into the atmosphere from coal-fired power plants and incinerators because coal and waste products often contain some arsenic. It cannot be destroyed in the environment. It can only change its form, or become attached to or separated from particles. It may change its form by reacting with oxygen or other molecules present in air, water, or soil, or by the action of bacteria that live in soil or sediment [52].

Researching the effects of arsenic accumulation from plants cultivated near pressure-treated wood, Cao and Ma [54] found out that elevated As concentrations were observed in the soils adjacent to fences and poles, because As was frequently used for wood treatment, in order to increase the wood life time. Eating vegetables from these contaminated soils may pose a risk of As exposure since vegetables would readily take up As from these soils.

As, according to the Agency for Toxic Substances and Disease Registry (ATSDR) [55] is the first substance on the Priority List of Hazardous Substances.

\subsection{Cadmium (Cd) - CAS ID 7440-43-9}

At room temperature $\left(25^{\circ} \mathrm{C} / 73.4^{\circ} \mathrm{F}\right)$ the $\mathrm{Cd}$ is presented at solid state, with atomic number of 48 and atomic mass of $112.41 \mathrm{~g}$. This element belong to the group of the metal of gray silver metallic color and it is available in many forms including sheet, granule, pellet, powder, rod, wire, among other. It is a soft metal, highly toxic which can be easily cut with a knife, and mostly produced as a byproduct of the extraction of $\mathrm{Zn}, \mathrm{Cu}$ and $\mathrm{Pb}$ [56].

It is considered one of the most toxic metals, presenting important harmful effects for biological activity on soil, plant metabolism, human and animal health. The abundance of $\mathrm{Cd}$ in magmatic and sedimentary rocks, generally not more than $0.3 \mathrm{mg} \mathrm{kg}^{-1}$, being that this metal tends to be concentrated in clayey deposits. The $\mathrm{Cd}$ is strongly associated to $\mathrm{Zn}$ in the geochemistry, however, have a strong affinity with S, presenting a higher mobility than $\mathrm{Zn}$ in acid environments [27].

Generally ore (CdS) is associated as a contaminant ( 0.25 to $0.5 \%)$ to ore $\mathrm{Zn}$ and $\mathrm{Pb}$. According to the International Cadmium Association [57], Cd has been mainly used in manufacturing NI-Cd batteries, though, also has other applications as pigments, coatings, stabilizers for PVC (polyvinyl chloride) and alloys.

One of the main problems associated with $\mathrm{Cd}$ is its final destination, because it can reach the soil or the air through the burning of urban waste or the burning of fossil fuels, in this way polluting the environment and causing damage to the ecosystem [58].

In humans, Cd affects several organ systems, as the Cardiovascular (Heart and Blood Vessels), Developmental (effects during periods when organs are developing), Gastrointestinal (Digestive), Neurological (Nervous System), Renal (Urinary System or Kidneys), Reproductive and Respiratory (From the Nose to the Lungs), Cd is also known as a carcinogen agent [52]. 
According to the Agency for Toxic Substances and Disease Registry [55] Cd is the seventh substance on the Priority List of Hazardous Substances.

\subsection{Lead (Pb) - CAS ID 7439-92-1}

The $\mathrm{Pb}$ is rarely found in its natural state, but in combination with other elements, being the most important ores which present this metal are: Galena, cerussite, anglesite, perite and others.

Among the toxic metals, $\mathrm{Pb}$ is present in larger amounts in the earth's crust, with an average concentration between 10 and $20 \mathrm{mg} \mathrm{kg}^{-1}$ [59], therefore, is among the most used metals worldwide scale of $\mathrm{Fe}>\mathrm{Al}>\mathrm{Cu}>\mathrm{Zn}>\mathrm{Pb}[60]$.

To be quite versatile, $\mathrm{Pb}$ is much used in industrial products, and can be hardened by the addition of other metals and metal alloy being used as producing components, welds and other materials, in addition to being able to form various compounds employed in chemical industry [61].

According to unofficial information from the National Department of Mineral Production (DNPM), the main consuming sectors $\mathrm{Pb}$ are: accumulators (batteries) $80 \%$, representing approximately 88 tons of metal, oxides, $12 \%$, equivalent to 13 tons; and electronic (alloys, solders and various), $8 \%$, with 9000 tons.

The $\mathrm{Pb}$ in soil is extremely stable and highly toxic to humans and animals, is currently ranked as the second most dangerous element in the Priority List of Hazardous Substances [55]. Most of the lead enters the human body through the respiratory and gastrointestinal routes, and after absorption, it can be found in the blood, soft and mineralized tissues [62].

In humans, the $\mathrm{Pb}$ poisoning may initially cause lack of appetite, metallic taste in mouth, muscle discomfort, malaise, headache and abdominal cramps strong. However, in childhood, symptoms often linked to the deposition of this metal in the brain are predominant. In its inorganic $\mathrm{Pb}^{2+}$ is an inhibitor of enzymes, further affecting the nervous system [63].

The organ systems affected by $\mathrm{Pb}$ are the Cardiovascular (Heart and Blood Vessels), Developmental (effects during periods when organs are developing), Gastrointestinal (Digestive), Hematological (Blood Forming), Musculoskeletal (Muscles and Skeleton), Neurological (Nervous System), Ocular (Eyes), Renal (Urinary System or Kidneys) and Reproductive [52].

\subsection{Chromium (Cr) - CAS ID 7440-47-3}

With regard to heavy metal $\mathrm{Cr}$, this has turned into a serious pollutant of air, soil and water. About $70 \%$ of the production of $\mathrm{Cr}$ is used in alloys, including stainless steel and $15 \%$ in industrial chemical processes, mainly in leather tanning, pigments, electrochemical and cooling towers [64].

The ions of $\mathrm{Cr}$ are found in different oxidation states, however, the trivalent form $\left(\mathrm{Cr}^{3+}\right)$ is the most common, while the hexavalent form $\left(\mathrm{Cr}^{6+}\right)$ depends on the more specific conditions of $\mathrm{pH}$ and redox potential [65]. 
The toxicity of $\mathrm{Cr}$ depends on its oxidation state. While the $\mathrm{Cr}^{3+}$ is relatively stable and immobile, the $\mathrm{Cr}^{6+}$ moves easily through the soil and aquatic environments, with a strong oxidizing agent capable of being absorbed even by the skin in this way, the $\mathrm{Cr}$ presents itself as a carcinogenic species $[66,67]$.

In humans, the Cr affects the immune, renal (kidney or urinary system) and respiratory tract (the nose to the lungs), and is known as a powerful carcinogen [52].

According to reference [68], a lethal dose of $\mathrm{Cr}^{6+}$ is between 50 and $100 \mathrm{mg} \mathrm{kg}^{-1}$, a value much lower when compared to $\mathrm{Cr}^{3+}$, the values are between 1900 and $3300 \mathrm{mg} \mathrm{kg}^{-1}$. Since the $\mathrm{Cr}^{6+}$ occupies the $17^{\text {th }}$ position in the Priority List of Hazardous Substances [55].

\subsection{Nickel (Ni) - CAS ID 7440-02-0}

The Ni occurs in the earth's crust in the order of $0.01 \%$, mainly as sulfide, oxide and silicate minerals. Geological activities as natural weathering and volcanoes led the natural distribution of this metal in natural environments at modest levels. The Ni metal and its compounds are used in multiple applications as stainless steel and other alloys, castings, catalysts, batteries, electronics, ceramics, pigments and even coins [69].

Among the main uses of this metal can still cite it use in coating parts, in a process called electroplating, widely used around the world by Electroplating industries [70].

Although not an element extensively released to the environment, this can present a risk to human health. Epidemiological investigations and experimental studies have shown that certain compounds of $\mathrm{Ni}$ are extremely carcinogenic after inhalation, however, the same studies show that these risks are limited by conditions specific occupational exposure to this metal [71].

Results show that this element can cross the placenta and present embryological and teratogenic properties. The main danger of $\mathrm{Ni}$ to the man beside the carcinogenicity is related to the ability to cause sensitivity reactions [71].

The most common harmful health effect in the general population is allergic contact dermatitis elicited by prolonged skin contact of sensitized individuals with Ni. Therefore, the majority of studies related to health effects of $\mathrm{Ni}$ to humans concern airborne Ni particulate matter. Strongest evidence for high cancer risk was found for sulfidic nickel species (NiS, $\mathrm{NiS}_{2}$ and $\mathrm{Ni}_{2} \mathrm{~S}_{3}$ ) in $\mathrm{Ni}$ refinery dust. On the molecular level the toxic Ni species responsible for severe health effects, as allergic contact dermatitis and respiratory tract cancer, has been suggested to be caused by $\mathrm{Ni}^{2+}$ [69].

$\mathrm{Ni}$ affects the following organ systems: Cardiovascular (Heart and Blood Vessels), Dermal (Skin), Immunological (Immune System), Respiratory (From the Nose to the Lungs) [52]. Actually, Ni ranks the $57^{\text {th }}$ position on the Priority List of Hazardous Substances [55].

\subsection{Copper (Cu)- CAS ID 7440-50-8}

The $\mathrm{Cu}$, despite being a heavy metal, meets the criteria of essentiality for plants and microorganisms, being classified as micronutrient [72]. This metal is essential to human health, and is 
present in all human tissues and many fluids and with amino acids, fatty acids and vitamins, is required for the metabolic processes [73].

Excess copper may be toxic to humans because of the affinity metal with S-H groups of many proteins and enzymes associated with diseases such as epilepsy, melanoma and rheumatoid arthritis, as well as the loss of taste [72]. Toxic levels of Cu occur naturally in some soils, whereas others may contain high levels of $\mathrm{Cu}$ as a result of the anthropogenic release of contaminated materials into the environment through mining, smelting, manufacturing, agriculture and waste disposal technologies [72].

In plants, either deficient or in excess, $\mathrm{Cu}$ can cause disorders in plant growth and development by adversely affecting important physiological process. In particular photosynthetic electron transport is altered under deficiency and excess of $\mathrm{Cu}$. Thus, for healthy plant growth and development $\mathrm{Cu}$ must be acquired from the soil, transported throughout the plant, distributed and compartmentalized within different tissues and its content carefully regulated within different cells and organelles. For this purpose, plants, like all other organisms, have homeostatic mechanisms to maintain the correct concentrations of essential metal ions. Membrane transport systems are likely to play a central role in these processes [73].

Copper ranks the $125^{\text {th }}$ position on the Priority List of Hazardous Substances [55].

\subsection{Manganese (Mn)- CAS ID 007439-96-5}

According to the International Manganese Institute (IMnI) [74], this metal is the fourth most used in terms of tonnage, being ranked behind $\mathrm{Fe}, \mathrm{Al}$ and $\mathrm{Cu}$, being the production of $\mathrm{Mn}$ alloys about 17.7 million metric tons at 2011. Mn the second major abundant metal and $12^{\text {th }}$ most abundant element in the earth's crust, being its ores deposits usually of sedimentary origin, with oxide ore layers inter-bedded with iron-rich formations [75].

Steel is basically an alloy of iron and carbon, consisting of an iron phase and iron carbides. Crude steel produced from iron contains an undesirable amount of oxygen and some sulphur. Mn plays a key role because of two important properties: its ability to combine with sulphur and its powerful deoxidation capacity [76].

High grade Mn ores (> 40\%) are typically processed into suitable metallic alloy forms by pyrometallurgical processes. Low grade manganese ores $(<40 \%)$ are conventionally processed by pyrometallurgical reductive roasting or melting followed by hydrometallurgical processing for production of chemical manganese dioxide (CMD), electrolytic manganese (EM) or electrolytic manganese dioxide (EMD) [77].

In the human body, Mn displays a somewhat unique behavior with regard to its toxicity. It is relatively non-toxic to the adult organism except to the brain where it causes Parkinson-like symptoms when inhaled even at moderate amounts over longer periods of time [78].

This element, when in large amounts, affect fertility in mammals and are toxic to the embryo and fetus, what implicates that pregnant women should not be exposed to Mn anytime [78].

Due to the substitution of $\mathrm{Pb}$ by $\mathrm{Mn}$ in gasoline, reference [79], researching the cultivation of beans and oats in soil next to roads, found not only Mn concentrations significantly higher in 
organic soil but also higher accumulation found in fruits and stems, suggesting that the addition of MMT to gasoline can be the cause for this increase in exchangeable Mn in organic soils.

According to the Agency for Toxic Substances and Disease Registry [55], Mn is the $140^{\text {th }}$ substance on the Priority List of Hazardous Substances.

\section{Case studies: Contaminated fertilizers in Brazilian crops}

Based on information obtained from seizures made in Brazilian seaports, related to the entry of loads of industrial waste with the presence of toxic metals for use as source of micronutrients in fertilizers [6], three studies were conducted to evaluate the possibility of soil and plants contamination using different sources and Zn levels, since this is main micronutrient applied in the Brazilian agricultural crops. All studies were conducted at the State University of West Paraná - Brazil, being one for soybean [2], one for the wheat crop [4] and the last one for the corn crop [5].

In the work done with the soybean crop [2], an experiment was conducted in 2007, in PalotinaPR, with coordinates $24^{\circ} 18^{\prime} \mathrm{S}$ and $53^{\circ} 55^{\prime} \mathrm{W}$ (Figure 2 ) in a soil classified as Hapludox (RED). It were used four different fertilizers for the Zn supply sold in Brazil, in three doses $(0.0 ; 0.9$ and $\left.1.8 \mathrm{~kg} \mathrm{ha}^{-1}\right)$. The results of this study demonstrated the presence of toxic metals $(\mathrm{Cd}, \mathrm{Pb}$ and $\mathrm{Cr}$ ) in the soybean leaf tissue (Table 5) at levels above of the tolerable in agricultural crops [27]. We also observed the occurrence of these three metals in the soil after harvest (Table 6), which compared to the Brazilian legislation, that establishes the maximum concentrations of contaminants in soils [28], classify the obtained values as above the maximum allowed for the soil be agriculturable (IV - Agricultural area) in the case of $\mathrm{Cd}$. For $\mathrm{Pb}$ and $\mathrm{Cr}$ the values obtained in the study were below of the prevention value (PV), which is the maximum allowable value of the contaminant in soil to that it is able to sustain its biological processes.

The work done with the wheat crop [4] was conducted on the residual fertilization of the work with the soybean crop, since the concentrations of the metals $\mathrm{Cd}, \mathrm{Pb}$ and $\mathrm{Cr}$ in the soil of the experiment were significant, especially in the case of $\mathrm{Cd}$. The results of this study showed no accumulation of $\mathrm{Cd}$ in the leaves of wheat at the level of detection by the analytical method (flame atomic absorption spectrometry - FAAS), however, we found concentrations of $\mathrm{Pb}$ and $\mathrm{Cr}$. For $\mathrm{Pb}$ the maximum concentration found was under the tolerable limit, and for the $\mathrm{Cr}$, the maximum concentration found was above the tolerable level for crops [27]. One of the main conclusions of this work was the occurrence of availability of $\mathrm{Cr}$ and $\mathrm{Pb}$ to wheat plants with fertilization performed in previous crop (soybean), demonstrating the persistence of contaminants in soil and their occurrence in more than one crop agriculture.

The work conducted with maize crop was conducted in Mercedes, Paraná State-Brazil, with geographic coordinates of $24^{\circ} 25^{\prime} \mathrm{S}$ and $54^{\circ} 15^{\prime} \mathrm{W}$ (Figure 3) in a Rhodic Eutrudox. The fertilization of this experiment was performed with eight different sources of $\mathrm{Zn}$ in four different doses $\left(0.0 ; 2.0 ; 4.0\right.$ and $\left.6.0 \mathrm{~kg} \mathrm{ha}^{-1}\right)$. In the chemical analysis performed in the fertilizers 


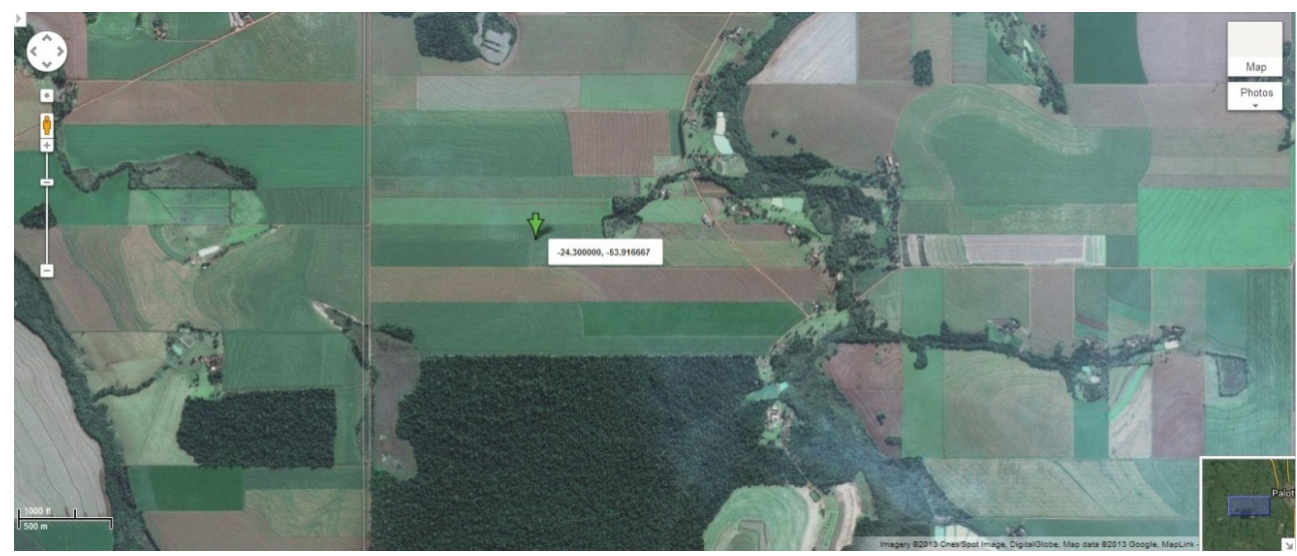

Figure 2. Local where the experiment involving fertilization with $\mathrm{Zn}$ in soybean and wheat culture were performed [80]

used in the work, it was observed that one of the sources presented $11039.46 \mathrm{mg} \mathrm{of} \mathrm{Pb} \mathrm{kg}^{-1}$, being the maximum limit permitted by Brazilian law (NI 27/06) [37] $10000.00 \mathrm{mg}$ of $\mathrm{Pb} \mathrm{kg}{ }^{-1}$ (Table 3). However, as previously mentioned in the section 3, the NI 27/06 tolerates the presence of contaminants up to $30 \%$ of the maximum permitted value, in this way, the fertilizer would not be considered as irregular, and can be freely traded.

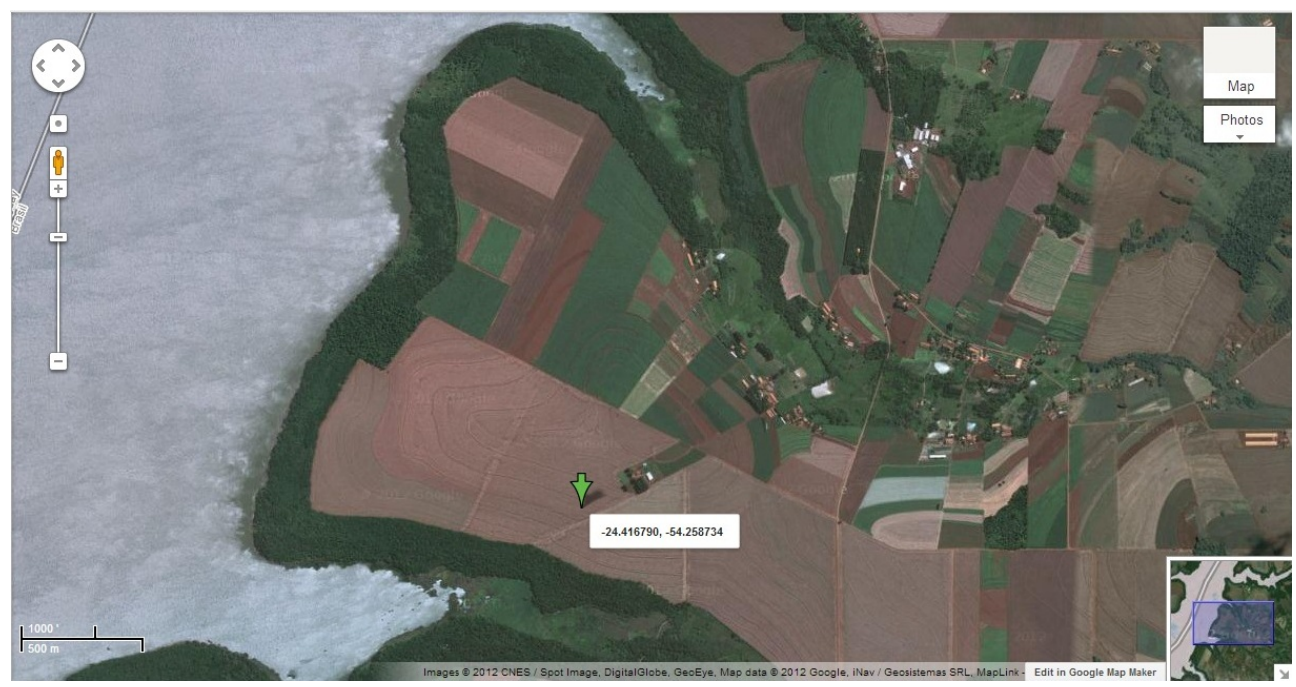

Figure 3. Local where the experiment involving fertilization with $\mathrm{Zn}$ in corn crop was performed [80] 
Regarding the leaf concentration of $\mathrm{Cd}, \mathrm{Pb}$ and $\mathrm{Cr}$ (Table 5), it was observed that only the $\mathrm{Pb}$ concentrations was found at detectable levels by the used method (FAAS), where the leaf content of $\mathrm{Pb}$ in corn plants can be considered inside the tolerable limits [27]. For the soil, it was observed the occurrence of $\mathrm{Cd}, \mathrm{Pb}$ and $\mathrm{Cr}$ (Table 6), so that the concentrations of $\mathrm{Cd}$ were below the maximum allowable limit so that the soil is agriculturable (IV - Agricultural area), and the $\mathrm{Pb}$ and $\mathrm{Cr}$ were below the $\mathrm{PV}$, which is the maximum allowable value of the contaminant in the soil, to that it be able to sustain its biological processes.

\begin{tabular}{lcccc}
\hline \multirow{2}{*}{ Metal } & Agricultural crop & & Tolerable foliar \\
\cline { 2 - 5 } & Soybean* & Wheat** & Corn*** & level**** \\
\hline $\mathrm{Cd}\left(\mathrm{mg} \mathrm{kg}^{-1}\right)$ & 0.73 & $\mathrm{ND}$ & $\mathrm{ND}$ & 0.05 a 0.50 \\
\hline $\mathrm{Pb}\left(\mathrm{mg} \mathrm{kg}^{-1}\right)$ & 25.53 & 1.95 & 8.67 & 0.50 a 10.00 \\
\hline $\mathrm{Cr}\left(\mathrm{mg} \mathrm{kg}^{-1}\right)$ & 3.36 & 9.28 & $\mathrm{ND}$ & 2.00 \\
\hline
\end{tabular}

ND - not detected by the method used (FAAS) with a quantification limit of $0.01 \mathrm{mg} \mathrm{L}^{-1}$; * - results from reference [2]; ** - results from reference [4]; ${ }^{* *}$ - results from reference [5]; ${ }^{* \star *}$ - Tolerable foliar level according to reference [27].

Table 5. Foliar levels of $\mathrm{Cd}, \mathrm{Pb}$ and $\mathrm{Cr}$ in experiments conducted with mineral fertilizers to supply $\mathrm{Zn}$ in different crops in Brazil

\begin{tabular}{|c|c|c|c|c|}
\hline \multirow[t]{2}{*}{ Metal } & \multicolumn{2}{|c|}{ Agricultural crop } & \multicolumn{2}{|c|}{$\begin{array}{l}\text { Classification of the metal value in } \\
\text { the soil* }\end{array}$} \\
\hline & Soybean* & Corn** & PV & IV - Agricultural area \\
\hline $\mathrm{Cd}\left(\mathrm{mg} \mathrm{dm}^{-3}\right)$ & 5.52 & 2.52 & 1.30 & 3.00 \\
\hline $\mathrm{Pb}\left(\mathrm{mg} \mathrm{dm}^{-3}\right)$ & 24.25 & 51.48 & 72.00 & 180.00 \\
\hline $\mathrm{Cr}\left(\mathrm{mg} \mathrm{dm}^{-3}\right)$ & 22.19 & 18.43 & 75.00 & 150.00 \\
\hline
\end{tabular}

Table 6. Levels of toxic metals $\mathrm{Cd}, \mathrm{Pb}$ and $\mathrm{Cr}$ in soil after cultivation of various crops fertilized with $\mathrm{Zn}$ in Brazil

Based on the results obtained in the three presented studies it can be inferred that the presence of metal contaminants in fertilizers is real and should be studied more carefully by regulatory authorities in Brazil. The foliar and soil levels of the metals $\mathrm{Cd}, \mathrm{Pb}$ and $\mathrm{Cr}$ found cause concern from the environmental point of view, due the possibility of entry of these contaminants in the food chain, either by consumption of contaminated materials or pollution of water resources from contaminants in the soil. It should be noted that the values presented in these works were obtained with only one fertilization, so that with successive fertilizations may occur a greater availability of these contaminants to the environment. 
It is worth affirm also that the laws related to the presence of contaminants [37], and levels of toxic heavy metals allowed in Brazilian soils [28], are being severely questioned by Brazilian researchers and government agencies. Among the key questions are the lack of criteria for determining and monitoring the presence of contaminants in fertilizers, passivity with the addition of toxic metals in brazilians soils by the minimum quality and lack of discussion with researchers and entities responsible for the drafting of legislation.

It should furthermore be highlighted that before approval of Resolution No. 420 of CONAMA [28], there was serious questioning on the part of Brazilian authorities and researchers in relation to the criteria used for its formulation by means of Proceeding 02000.002955/2004-69 [81-83], thus confirming the need for more societal discussion (especially among the specialized technical and scientific segments in a multidisciplinary manner) before this is submitted for approval of possible resolution. The resolution, moreover, violates the Brazilian Federal Constitution with respect to the "preservation, improvement and recovery of the environmental quality favorable to life" because it permits the introduction of contaminants in the soil up to the maximum limit permitted by the resolution, thus allowing the use of contaminated fertilizers and soil conditioners in agriculture until they reach and exceed these values and thereby degrade environmental quality. Therefore, the need for more in-depth field studies in relation to environmental legislation before it is drafted and approved becomes clear. These studies must be undertaken together with environmental regulatory bodies and research entities in the country. Based on the results obtained in this study, it is evident that some of the $\mathrm{Zn}$ fertilizer sold by sources in Brazil significantly affect the quantity of $\mathrm{Cd}, \mathrm{Pb}$, and $\mathrm{Cr}$ in soil. If their use is continued, there may be contamination of soil, surface and underground waters, plants, animals, and humans, leading to severe damage to health as well as the environment. This fact raises concern because according to references [84-86], even low levels of heavy metals in soil may be available to plants, an effect that is difficult to ascertain because the symptoms they case occur only over the long term, thus increasing even more the hazards associated with the use of contaminated materials in agricultural activities.

In a review about the environmental risks of adding phosphate fertilizers contaminated with trace elements in long-term, reference [87] warn about the possibility of increasing concentrations of $\mathrm{As}, \mathrm{Cd}$ and $\mathrm{Pb}$ in agricultural soils using contaminated fertilizers. The authors also emphasize that to prevent the entry of potentially toxic elements in agriculture, it is necessary a strict control on the sources of macro and micronutrients used in agriculture. This demonstrates the importance and need for further studies related to the use of fertilizers contaminated with toxic metals in crops and the environmental impacts that these sources of nutrients can cause.

\section{Sustainable strategies for soil remediation}

The introduction of toxic chemicals by man in various environmental compartments (soil, water and atmosphere), the of controlled or uncontrolled elimination of wastes (accidental spills, mining processes and smelting of metallic ores, fertilizer application, sewage sludge and 
pig manure in agricultural soils) puts the ability to self-cleaning of contaminated ecosystems in doubt. Consequently, the pollutants that accumulate toxic metals are of concern in relation to human exposure of ecosystems and the potential impact [88].

Today there are several techniques for soil decontamination. It is worth mentioning that the choice of one or other technique, among other factors, also depends on the characteristics of the contaminant in question, between the different techniques is possible enumerate:

1. Thermal treatment: Use of heat to remove, stabilize or destroy the contaminants;

2. Physical treatment: Physical processes used to separate toxic substances from the environment;

3. Chemical treatment: Uses chemical reactions to remove, destroy or modify toxic substances;

4. Biological treatment: Makes use of natural metabolic means, such a microorganisms and other biological agents to remove, destroy or modify the contaminants;

5. Stabilization / solidification: This step the contaminants are stabilized chemically and / or modified to reduce the potential for contamination.

These technologies can in many cases be applied "in situ", i.e., at the site of origin of the contamination, or "ex situ" outside the place of contamination, which results in the removal and transport of the contaminated soil.

Among the physical-chemical treatments, these mostly are based on soil washing. These methods are based on the technological principle of the transfer of a contaminant from the soil for a liquid or gaseous phase. The main products are treated soil and the contaminants concentrated. The specific process of treatment depends on the type of contaminant, in particular as regards the type of connection established with the soil particles.

It is observed by the description above, that such treatments become process more expensive the decontamination because are many cases in which the soil treatment requires the removal of several layers of the same and specific treatment in laboratories.

Thus, many approaches have been developed, evaluated and performed to deal with soil pollution. Current technologies for decontamination soil are often expensive and of high energy consumption, and in many cases, the soil cannot be reused after treatment [89]. Thus, several studies have been developed to promote proper techniques and low cost of remediation in order to prevent the spread of these contaminants in the food chain $[88,90]$.

As an alternative, an ecological approach technology that involves the use of plants to clean up or remediate soils contaminated with toxic metals, called phytoremediation, has been developed and encouraged by the fact of being a simple and inexpensive option for remediation of contaminated soils [90-92].

Phytoremediation can be divided into phytoextraction (hiperacumulation) phytostabilization, rhizofiltration, fitotransformation and fitovolatilization (Figure 4). 


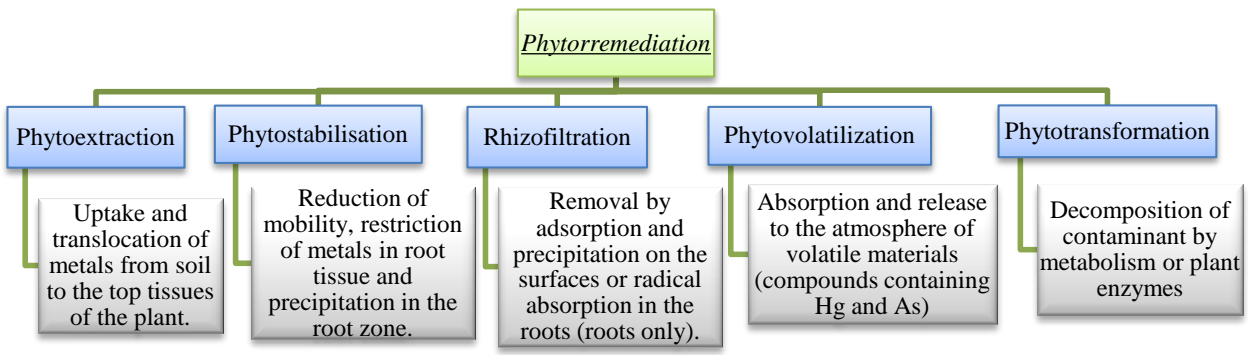

Figure 4. Types and characteristics of phytoremediation $[92,93]$

However for the phytoremediation to be effective it depends on the selection of plant species, preferably hyperaccumulators, which are able to grow in soils of low fertility, and degraded by the presence of contaminants [94].

In studies carried out in Iran using Euphorbia macroclada and Centaurea virgata, demonstrate that the sampled species not only were able to grow in soils highly contaminated by metals, as well as were capable of accumulating high concentrations of $\mathrm{Zn}, \mathrm{Mn}, \mathrm{Cu}, \mathrm{Pb}$ and $\mathrm{Fe}$, in this way these plants can be classified as hyperaccumulators, in other words, have adequate potential for phytoremediation of contaminated soils [95].

However, the metal accumulation by the plants is only efficient after the contaminant be removed from the soil, for example, by harvesting the plant matter. If most of the toxic metals are located on the shoots, the harvest can be performed using traditional farming methods. In general, it is necessary to harvest the plants before the fall of the leaves, or before his death and decomposition, so that contaminants do not disperse or return to the soil.

After harvesting, the biomass must be processed for extraction and recollection of the majority of metals. Alternatively, the volume and the weight of the biomass can be reduced by thermal processes, physical, chemical or microbial. In the case of burning plant, for example, the energy produced represents an economic value of the process and the ash may be treated as an ore, which may still be extracted the metallic contaminant (especially if the ashes are enriched in one or two metals).

Even Brazil showing great potential species for bioremediation and phytoremediation, the recovery of contaminated areas, due to the great biodiversity and climate, favoring biological processes in pollution treatment, knowledge about these species of plants and microbial communities in phytoremediation potential are still scarce [96].

In research carried out by reference [97], it was reported that some plants were able to remediate soils contaminated with metals such as Brassica juncea for phytoextraction of $\mathrm{Cd}$ and $\mathrm{Cr}^{6+}, \mathrm{Cu}, \mathrm{Ni}$ and $\mathrm{Pb}$, Avena sativa for $\mathrm{Zn}$, Pisum sativum L. and Zea mays L. for removal of $\mathrm{Pb}$.

However, from an economic point of view, the use of these species of accumulator plants generally do not generate financial returns to the farmers, because these plants only remove the contaminant from the soil, being later discarded after the remediation. Thus if the farmer 
in question require to decontaminate a particular area, the phytoremediation only would generate costs, especially with seeds, agricultural machinery, irrigation, etc.

Nevertheless, currently there is a widespread idea that the species used for phytoremediation of soil can also generate economic gains beyond decontamination. The use of oil crops, for example, Crambe abyssinica H., Moringa oleifera L. and Jatropha curcas, in which the product marketing is not consumed as food, but as biofuel (biodiesel), is a possibility to decrease the cost of recovery of the contaminated area. Thus the fact that the plant has accumulated large amounts of heavy metal will have little influence on the end product of the culture, generating profit for the property.

Moreover, oil crops like C. abyssinica, M. oleifera and J. curcas, have been the subject of research in the removal of toxic metals such as $\mathrm{Cd}, \mathrm{Pb}, \mathrm{Cr}$ and water through the adsorption process, in which the pie their seeds are used as adsorbent [98-101]. The results of these studies demonstrated great potential for removal of these metals, and that these adsorbents are obtained at minimal charges, because they are wastes generated by the extraction of vegetable oil.

Thus, the use of cultures for vegetable oil production and recovery of contaminated areas can be an interesting alternative, which will generate the money from oil production and recovery / stabilization of the contaminated area with the development of these cultures, preventing them be lost through leaching or soil surface runoff and reach the groundwater and surface water and groundwater. However, more researches are still needed In order to evaluate this possibility, focusing on the development of oil-producing plants and cycles of addition of the adsorbent material and the biodegradability thereof. Between this and other issues to which scientific research is driven, many studies still need to be developed so that, in one way or another, the quest for sustainability will one day be achieved.

\section{Conclusion}

Based on information existing in the Brazilian and international literature, we can make some important observations:

The fertilization of plants is one of the major reasons of the increase in food production across the globe. Consequently, the use of fertilizers in agricultural crops is extremely high and growing, however, for the maintenance of this production capacity, we should be very careful with the fertilizers sources that are being used in agriculture.

The presence of toxic metals in fertilizers has been reported in the major food producing countries, like United States, China and Brazil. This demonstrates that this issue deserves further detailed studies of long-term about the successive addition and the effects of these contaminants to crops, soil, supply chain and the wider environment. Thus, the institutions of research and supervision, have to evaluate the products that are used for the manufacture of fertilizers on the market, as this is an activity that generate large amounts of money and that will always be a target of people with questionable character. 
The current legislation, not only in Brazil, but internationally, with respect to the use of wastes as sources of nutrients, presence of contaminants in fertilizers and presence of toxic metals in soil, need higher accompaniments and answers for some of the community questions, because the legislation must ensure that the agricultural soils are not being degraded and becoming unproductive. In Brazil, it is strongly recommended that the laws must be harder and restrictive, until we have reliable and conclusive results related to the addition of contaminated fertilizer in long-term. In this case, it should be emphasized that these laws should be developed based on results from institutional researches and reliable groups, without the influence of political and industrial groups. Meanwhile, the damage caused by man in air, soil and waters, must be repaired, by remediation methods (such as phytoremediation) aiming not only the decontamination, but also ensuring a small profit, as an incentive to the farmer.

Brazil is considered as one of the countries with largest biodiversity and most promising in food production for the globe, however, for that prediction become a reality, it is very important that the productive areas are not degraded. The technologies developed by our civilization provide ways to avoid the degradation of our environment, but often they are not used because they prevent higher industrial profits, this should not occur, because the balance of the ecosystem and the quality of human life should be above of any monetary profit.

\section{Author details}

Affonso Celso Gonçalves Jr. ${ }^{1}$, Herbert Nacke ${ }^{2}$, Daniel Schwantes ${ }^{3}$ and Gustavo Ferreira Coelho ${ }^{4}$

*Address all correspondence to: affonso133@hotmail.com

1 Western Paraná State University, Center of Agricultural Sciences, Marechal Cândido Rondon, Brazil

2 University Center Dynamic of Cataracts, Technological Center, Foz do Iguaçu, Brazil

3 Pontifical Catholic University of Paraná, Polytechnic School, Toledo, Brazil

4 Federal University of Paraná, Palotina, Brazil

\section{References}

[1] Nacke H, Gonçalves Jr AC, Stangarlin JR,Schwantes D, Strey L, Nava I. Productivity and yield components of maize fertilized with different sources and doses of zinc. Spanish Journal of Rural Development 2011;2(1) 47-55. 
[2] Nava I, Gonçalves Jr AC, Nacke H, Guerini VL, Schwantes D. Availability of cadmium, lead and chromium toxic heavy metals in soil and soybean leaf tissue fertilized with different sources of NPK+Zn. Ciência e Agrotecnologia 2011;35(1), 884-892.

[3] Gonçalves Jr AC, Nacke H, Marengoni, NG, Carvalho, EA, Coelho GF. Yield and production components of soybean fertilized with different doses of phosphorus, potassium and zinc. Ciência e Agrotecnologia 2010;34(3) 660-666.

[4] Gonçalves Jr AC, Nacke H, Schwantes D, Nava IA, Strey L. Phytoavailability of toxic heavy metals and productivity in wheat cultivated under residual effect of fertilization in soybean culture. Water, Air and Soil Pollution 2011;220(1) 205-211.

[5] Nacke H, GonçalvesJr AC, Schwantes D, Nava I, Strey L, Coelho GF. Availability of heavy metals $(\mathrm{Cd}, \mathrm{Pb}$ and $\mathrm{Cr})$ in agriculture from commercial fertilizers. Archives of Environmental Contamination and Toxicology 2013;64(1), 371-379.

[6] Gonçalves Jr AC, Luchese EB, Lenzi E. Evaluation of phytoavailability of the cadmium, lead and chromium in soybean cultivated in the Latossolo vermelho escuro, treated with commercial fertilizers. Química Nova 2000;23(2) 173-177.

[7] Manzatto CV, Freitas Junior E, Peres JRR. Agricultural use of Brazilian soils. Rio de Janeiro: Embrapa Solos; 2002.

[8] FAO - Food and Agriculture Organization of the United Nations. The state of food and agriculture: Women in agriculture closing the gender gap for development. Rome: FAO; 2011.

[9] Nelson GC, Rosegrant MW, Palazzo A, Gray I, Ingersoll C, Robertson R, Tokgoz S, Zhu T, Sulser TB, Ringler C, Msangi S, You L. Food Security, Farming, and Climate Change to 2050: scenarios, results, policy options. Washington: International Food Policy Research Institute; 2010.

[10] Foley JA, Ramankutty N, Brauman KA, Cassidy ES, Gerber JS, Johnston M, Mueller ND, O'Connell C, Ray DK, West PC, Balzer C, Bennett EM, Carpenter SR, Hill J, Monfreda C, Polasky S, Rockstrom J, Sheehan J, Siebert S, Tilman D, Zaks DPM. Londons: Solutions for a cultivated planet. Nature 2011;478(1) 337-342.

[11] International Fertilizer Industry Association. http://www.fertilizer.org/ifa/ifadata/ search (accessed 15 June 2013).

[12] Yamada T. Deficiências de micronutrientes, ocorrência, detecção e correção: o sucesso da experiência brasileira. Piracicaba: Potafos; 2004.

[13] Cakmark I. Plant nutrition research: Priorities to meet human needs for food in sustainable ways. Plant and Soil 2002;247(1) 03-24.

[14] Gonçalves Jr AC, Pessoa ACS. Phytoavailability of the cadmium, lead and chromium in soybean cultivated in argissolo vermelho eutrófico, treated with commercial fertilizers. Scientia Agrária2002;3(1-2) 19-23. 
[15] CETESB - Environmental Sanitation Technology Company of São Paulo State. Relation of contamined areas in São Paulo 2012. http://www.cetesb.sp.gov.br/userfiles/ file/areas-contaminadas/2012/texto-explicativo.pdf (accessed 15 June 2013).

[16] Lopes JC, Ribeiro LG, Araújo MG, Beraldo MRBS. Lettuce production using doses of sewage sludge. HorticulturaBrasileira 2005;23(1), 143-147

[17] Pegorini ES, Andreoli CV. Introduction. In: Andreoli, CV. (ed.) Alternative use of sanitary waste. São Paulo:ABES; 2006. p01-06.

[18] Marques MO, Nogueira TAR, Fonseca IM, Marques TA. Cr, Ni, Pb e Zn contents in sewage sludge added Red Argisol and sugarcane cropped. Revista de Biologia e Ciência da Terra2007;27(1) 133-143.

[19] Alamino RCJ, Polivanov H, Campos TMP, Silva VHG, Santos LV, Mendes JC. Bioavailability of Cadmium on a Latosol Increased of Sewage Sludge. Anuário do Instituto de Geociência 2007;30(2) 45-54.

[20] CETESB - Environmental Sanitation Technology Company of São Paulo State. Report establishment of guiding values for soils and groundwater in the State of São Paulo. São Paulo: CETESB; 2001.

[21] Mattias JL, Ceretta CA, Nesi CN, Girotto E, Trentin EE, Lourenzi CR, Vieira RCB. Copper, zinc and manganese in soils of two watersheds in Santa Catarina with intensive use of pig slurry. Revista Brasileira de Ciência do Solo 2010;34(4) 1445-1454.

[22] Wu L, Tan C, Liu L, Zhu P, Peng C, Luo Y, Christie P. Cadmium bioavailability in surface soils receiving long-term applications of inorganic fertilizers and pig manure. Geoderma 2012;173-174(1) 224-230.

[23] Ramalho JFGP, Sobrinho NMB, Velloso ACX. Heavy metals contamination of a watershed in Caetés by the use of agrochemicals. Pesquisa Agropecuária Brasileira 2000;35(7) 1289-1303.

[24] Baker DE. Copper. In: Alloway, BJ. (ed.) Heavy metals in soils. Glasgow: Blackie and Son; 1990. p.51-74.

[25] Nicholson FA, Smith SR, Alloway BJ, Carlton-Smith C, Chambers BJ. An inventory of heavy metals inputs to agricultural soils in England and Wales. The Science of the Total Environment 2003;311(1) 205-219.

[26] Council Directive of 12 June 1986 on the protection of the environment, and in particular of the soil, when sewage sludge is used in agriculture (86/278/EEC). http://eurlex.europa.eu/LexUriServ/LexUriServ.do?uri=CELEX:31986L0278:EN:HTML (accessed 15 July 2013).

[27] Kabata-Pendias A, Pendias H. Trace elements in soils and plants. 3rd ed. Boca Raton: CRC Press; 2001.

[28] Brazil. Resolution 420. Brasília: Ministry of the Environment; 2009. 
[29] Novais RF, Alvarez VVH, Barros NF, Fontes RLF, Cantarutti RB, Neves JCL. editors. Soil Fertilty: Viçosa: SBCS; 2007.

[30] USEPA - United States Environmental Protection Agency. Background Report on Fertilizer Use, Contaminants and Regulations. Columbus: USEPA; 1999.

[31] The Weinberg Group. Scientific Basis for Risk-Based Acceptable Concentrations of Metals in Fertilizers and Their Applicability as Standards. Washington: The Weinberg Group; 2001.

[32] USEPA - United States Environmental Protection Agency. Zinc fertilizers made from recycled hazardous secondary materials. Washington: USEPA; 2002.

[33] WDE - Washington Department of Ecology. Focus: Imported Cadmium-Contaminated Zinc Sulfate Used in Fertilizer and Other Products. Washington: WDA; 2000.

[34] Gabe U, Rodella AA. Trace elements in Brazilian agricultural limestones and mineral fertilizers. Communications in Soil Science and Plant Analysis 1999;30(5-6) 605-620.

[35] Martins ALC, bataglia OC, Camargo AO, Cantarella H. Corn yield and uptake of Cu, $\mathrm{Fe}, \mathrm{Mn}$ and $\mathrm{Zn}$ from sewage sludge-amended soil with and without liming.Revista Brasileira de Ciência do Solo 2003;27(3) 563-574.

[36] Brazil. NormativeInstruction 27. Brasília: Ministry of Agriculture, LivestockandSupply; 2006.

[37] Hooda SP. Trace Elements in Soils. London: Wiley; 2010.

[38] CCR - California Code of Regulations. Standards and labeling. California: CCR; 2007.

[39] AAPFCO - Association of American Plant Food Control. AAPFCO's Statement of Uniform Interpretation and Policy (SUIP) \#25: the heavy metal rule. http:// www.aapfco.org/rules.html (accessed 15 June 2013).

[40] AFPC - Association of Fertilizer and Phosphate Chemists. Latest Metal Regulations in Fertilizers. http://afpc.net/Metal\%20Regulations.html (accessed 15 June 2013).

[41] ABNT - Brazilian National Standards Organization. NBR 10004. Rio de Janeiro: ABNT; 2004.

[42] Rodella AA. Regulation of contaminant contents in fertilizers: A Case study. Revista Brasileira de ciência do solo 2005; 29(1) 797-801.

[43] Pino GAH. Biosorption of heavy metals using Cocos nucifera. Master's Dissertation. Pontifical Catholic University; 2005.

[44] Morillo J, Usero J, Gracia I. Partitioning of metals in sediments from the Odiel river (Spain). Environment International 2002;28(4) 263-271. 
[45] Bueno BYM. Removal of $\mathrm{Pb}, \mathrm{Cr}$ and $\mathrm{Cu}$ by a Combined Biosorption / Bioflotation process using a Rhodococcusopacus straint. Doctorate Thesis. Pontifical Catholic University; 2007.

[46] Nriagu JO, Pacyna JM. Quantitative assessment of worldwide contamination of air, water and soils by trace metals. Nature 1988;333(1) 134-139.

[47] Loska K, Wiechula D, Korus I. Metal contamination of farming soils affected by industry. Environmental International 2004;30(1) 159-165.

[48] Naimo TJ. A review of the effects of heavy metals on freshwater mussels. Ecotoxicology 1995;4(6) 341-362.

[49] Sayler GS, Nelson Jr JD, Colwell RR. Role of bacteria in bioaccumulation of mercury in the oyster Crassostrea virginica. Applied Microbiology 1975;30(1) 91-96.

[50] Peralta-Videa JR, Lopez ML, Narayan M, Saupe G, Gardea-Torresdey J. The biochemistry of environmental heavy metal uptake by plants: Implications for the food chain. The international Journal of biochemistry \& Cell Biology 2009;41(8-9) 1665-1677.

[51] ATSDR - Agency for Toxic Substances and Disease Registry. Toxic Substances Index. http://www.atsdr.cdc.gov/az/a.html (accessed 15 June 2013).

[52] Rahman MA, Hasegawa H, Lim PR. Bioaccumulation, biotransformation and trophic transfer of arsenic in the aquatic food chain. Environmental Research 2012;116(1) 118-135.

[53] Cao X, MA LQ. Effects of compost and phosphate on plant arsenic accumulation from soils near pressure-treated wood. Environmental Pollution 2004;132(3) 435-442.

[54] ATSDR - Agency for Toxic Substances and Disease Registry. The Priority List of Hazardous Substances. http://www.atsdr.cdc.gov/SPL/index.html (accessed 15 June 2013).

[55] Brady JE, Humiston GE. General Chemistry. $2^{\text {th }}$ ed. Rio de Janeiro: Livros Técnicos e Científicos; 1986.

[56] ICdA. INTERNACIONAL Cadmium ASSOCIATION, Revision of the Battery Directive: Public Consultation, 2001.

[57] PINO G.A.H., Biossorption of Heavy metals on green coconut powder. Master Dissertation, PUC-RJ, March, 113p. 2005.

[58] Paoliello MMB, Chasin AAM. Ecotoxicology of lead and its compounds. Salvador: CRA; 2001.

[59] ILZSG - International Lead and Zinc Study Group. Statistic of Lead and Zinc. 2010. http://www.ilzsg.org/static/home.aspx (accessed 15 June 2013). 
[60] Kreush MA. Assessment with proposals for improving the industrial process of recycling lead and indicating applicability to slag generated. Master's Dissertation. Federal University of Parana; 2005.

[61] ATSDR - Agency for Toxic Substances and Disease Registry. Case studies in environmental medicine: lead toxicity. Atlanta: ATSDR; 1999.

[62] Capitani EM. Diagnosis and treatment of lead poisoning in children and adults. Medicina 2009;42(3) 319-329.

[63] Cervantes C, Campos-García J, Devars S, Gutiérrez-Corona F, Loza-Tavera H, Torres'Guzmán JC, Moreno-Sánchez R. Interactions of chromium with microorganisms and plants. FEMS Microbiology Reviews 2001;25(3) 335-347.

[64] WHO - World Health organization. Environmental health criteria 61 - Chromium. Geneva: WHO; 1988.

[65] Smith WLE, Gadd GM. Reduction and precipitation of chromate by mixed culture sulphate-reducing bacterial biofilms. Journal of Applied Microbiology 2000;88(6) 983-991.

[66] Kumral E. Speciation of chromium inwaters via sol-gel preconcentration prior to atomic spectrometric determination. Doctorate Thesis. The Graduate School of Engineering and Sciences of Izmir Institute of Technology; 2007.

[67] Frois SR, Grassi MT, Fernandes TC, Barreto RAS, Abate G. Preconcentration of Cr(III) and speciation analysis of chromium employing montmorillonite saturated with potassium ions. Química Nova 2011;34(3) 462-467.

[68] Schaumlöffel D. Nickel species: analysis and toxic effects. Journal of Trace Elements in Medicine and Biology 2012;26(1) 1-6.

[69] Veit MT, Silva EA, Fagundes-Klen MR, Tavares CRG, Gonçalves GC. Biosorption of nickel and chromium from a galvanization effluent using seaweed pre-treated on a fixed-bed column. Acta Scientiarum. Technology 2009; 31(2) 175-183.

[70] Leonard A, Gerber P, Jacquet P. Carcinogenicity, mutagenicity and teratogenicity of nickel.Mutation. Research/Reviews in Genetic Toxicology 1981;87(1) 1-15.

[71] Sodré FF, Lenzi E, Costa ACS. Applicability of adsorption models to the study of copper behaviour in clayey soils. Química Nova 2001;24(3) 324-330.

[72] Lima AJB, Cardoso, MG, Guerreiro MC, Pimentel FA. Using activated carbon to remove copper from sugar cane spirit. Química Nova 2006;29(2) 247-250.

[73] Yruela I. Copper in plants. Brazilian Journal of Plant Physiology 2205;17(1) 145-156.

[74] International Manganese Institute. Applications of Mn. http://www.manganese.org/ about_mn/applications (accessed 15 June 1013). 
[75] Das AP, Sukla LB, Pradhan N, Nayak S. Manganese biomining: A review. Bioresource Technology 2011;102(16) 7381-7387.

[76] Zhang W, Cheng, CY. Manganese metallurgy review. Part I: Leaching of ores/secondary materials and recovery of electrolytic/chemical manganese dioxide. Hydrometallurgy 2007;89(3-4) 137-159.

[77] Gerber GB, Leonard A, Hantson PH. Carcinogenicity, mutagenicity and teratogenicity of manganese compounds. Critical Reviews in Oncology/Hematology 2002;42(1) 25-43.

[78] Brault N, Loranger S, Courchesne F, Kennedy G, Zayed J. Bioaccumulation of manganese by plants: influence of MMT as a gasoline additive. Science of the Total Environment 1994;153(1-2) 77-84.

[79] Google. Google Maps. https://maps.google.com (accessed 15 June 2013).

[80] Paula Jr D. Office 2147/09-MP-PJCS-UMA. http://www.mma.gov.br/port/conama/ processos/FE4582B1/Of2147-09-MP-PJCS-U MA_7maio09.pdf. 2009. (accessed 15 June 2013).

[81] Varjabedian R, Leite CBB. Office 1029/2009 - PGJ/CAO. http://www.mma.gov.br/ port/conama/processos/FE4582B1/ConsideracoesMinisPublSaoPaulo.pdf. 2009 (accessed 15 june 2013).

[82] Brazilian Ministry of the Environment. Process 02000.002955/2004-69. 2011. http:// www.mma.gov.br/port/conama/processo.cfm?processo=02000.002955/2004-69 (accessed 15 June 2013).

[83] Gimeno-García E, Andreu V, Boluda R. Heavy metals incidence in the application of inorganic fertilizers and pesticides to rice farming soils. Environmental Pollution 1996;92(1) 19-25.

[84] Ryser P, Sauder WR. Effects of heavy-metal-contaminated soil on growth, phenology and biomass turnover of Hieraciumpiloselloides. Environmental Pollution 2006;140(1) $52-61$.

[85] Jan FA, Ishaq M, Khan S, Ihsanullah I, Ahmad I, Shakirullah M. A comparative study of human health risks via consumption of food crops grown on wastewater irrigated soil (Peshawar) and relatively clean water irrigated soil. Journal of Hazardous Materials 2010;179(1-3) 612-621.

[86] Jiao W, Chen W, Chang AC, Page AL. Environmental risks of trace elements associated with long-term phosphate fertilizers applications: A review. Environmental Pollution 2012;168(1) 44-53.

[87] Ghosh M, Singh SP. A Review on Phytiremediation of heavy metals and utilization of its byproducts. Applied ecology and environmental research 2005;3(1) 1-18. 
[88] Lorestani B, Cheraghi M, Yousefi N. Phytoremediation Potencial of Native Plants Growing on a Heavy Metals Contaminated soil of Copper mine in Iran. World Academy of Science, Engineering and Technology 2011;53(1) 377-382.

[89] Susarla S, Medina VF, McCutcheon SC. Phytoremediation: An ecological solution to organic chemical contamination Ecological Engineering 2002;18(1) 647-658.

[90] Gratão PL, Prasad MNV, Cardoso PF, Lea PJ, Azevedo RA. Phytoremediation: Green technology for the clean up of toxic metals in the environment. Brazilian Journal of Plant Physiology 2005;17(1) 53-64.

[91] Lorestani B, Cheraghi M, Yousefi N. Accumulation of $\mathrm{Pb}, \mathrm{Fe}, \mathrm{Mn}, \mathrm{Cu}$ and $\mathrm{Zn}$ in plantsand choice of hyperaccumulator plant in the industrial town of viean, Iran. Archives of Biological Science Belgrade 2011; 63(3) 739-745.

[92] Jing $Y$, He Z, Yang X. Role of soil rhizobacteria in phytoremediation of heavy metal contaminated soils Journal of Zhejiang University Science B 2007;8(3) 192-207.

[93] Mkumbo S, Mwegoha W, Renman G. Assessment of the phytoremediation potential for $\mathrm{Pb}, \mathrm{Zn}$ and $\mathrm{Cu}$ of indigenous plants growing in a gold mining area in Tanzania. International Journal of Environmental Sciences 2012;2(4) 2425-2434.

[94] Cheraghi, M,Lorestani, B,Yousefi, N. Introduction of Hyperaccumulator Plants with Phytoremediation Potential of a Lead- Zinc Mine in Iran. World Academy of Science, Engineering and Technology 2011, 53(1) 163-168.

[95] Marques M, Aguiar CRC, Silva JJLS. Technical challenges and social, economic and regulatory barriers to phytoremediation of contaminated soils. Revista Brasileira de Ciência do Solo 2011;35(1) 1-11.

[96] Prasad MNV, Freitas HMO. Metal hyperaccumulation in plants - Biodiversity prospecting for phytoremediation technology.Eletronic Journal of Biotechnology 2003;6(3) 285-321.

[97] Gonçalves Jr. AC, Rubio F, Meneghel AP, Coelho GF, Dragunski DC, Strey L. The use of Crambe abyssinica seeds as adsorbent in the removal of metals from waters. Revista Brasileira de Engenharia Agrícola e Ambiental 2013;17(2) 306-311.

[98] Rubio F, Gonçalves Jr. AC, Meneghel AP, Tarley CRT, Schwantes D, Coelho GF. Removal of cadmium from water using by-product Crambe abyssinca Hochst seeds as biosorbent material. Water Science and Technology 2013;68(1) 227-233.

[99] Rubio F, Gonçalves Jr. AC, Strey L, Meneghel AP, Coelho, GF, Nacke, H. Applicability of Crambe abyssinica Hochst byproduct as biosorbent in the removal of chromium from water. Spanish Journal of Rural Development. 2013;4(1) 25-40.

[100] Gonçalves Jr. AC, Meneghel AP, Rubio F, Strey L, Dragunski DC, Coelho GF. Applicability of Moringa oleifera Lam. pie as an adsorbent for removal of heavy metals from waters. Revista Brasileira de Engenharia Agrícola e Ambiental 2013;17(1): 94-99. 
[101] Nacke H, Gonçalves Jr. AC, Coelho GF, Strey L, Schwantes D, Laufer A. Removal of cadmium from aqueous solutions by adsorption on Jatropha biomass In: Bartolo $\mathrm{H}$. (ed.) Green Design, Materials and Manufacturing Processes. Boca Raton: CRC Press Taylor \& Francis Group; 2013. p367-372. 
